INTERNATIONAL MONETARY FUND

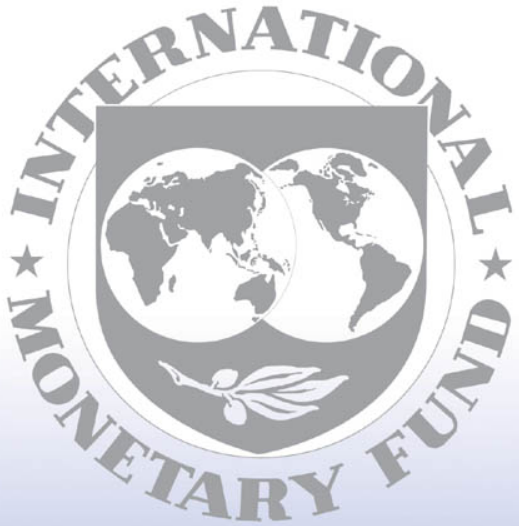

Staff

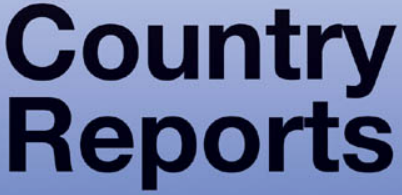




\section{Mexico: Selected Issues}

This Selected Issues paper for Mexico was prepared by a staff team of the International Monetary Fund as background documentation for the periodic consultation with the member country. It is based on the information available at the time it was completed on January 15, 2009. The views expressed in this document are those of the staff team and do not necessarily reflect the views of the government of Mexico or the Executive Board of the IMF.

The policy of publication of staff reports and other documents by the IMF allows for the deletion of market-sensitive information.

Copies of this report are available to the public from

International Monetary Fund $\bullet$ Publication Services

700 19th Street, N.W. • Washington, D.C. 20431

Telephone: (202) 623-7430 • Telefax: (202) 623-7201

E-mail: publications@imf.org • Internet: http://www.imf.org

\section{International Monetary Fund Washington, D.C.}


This page intentionally left blank

CInternational Monetary Fund. Not for Redistribution 


\section{INTERNATIONAL MONETARY FUND}

\section{MEXICO}

\section{Selected Issues}

Prepared by R. Blavy, H. Kamil, K. Magnusson, S. Phillips, and C. Walker (all WHD); and M. Souto (MCM)

Approved by the Western Hemisphere Department

January 15, 2009

Contents

Executive Summary

I. The Significance of U.S. Regional Economic Conditions for Remittances to Mexico $\underline{3}$

II. Exchange Rate Exposure of the Mexican Corporate Sector: Progress and Remaining Vulnerabilities $\underline{6}$

III. Estimating Default Frequencies and Macrofinancial Linkages in the Mexican Banking System 


\section{EXECUTIVE SUMMARY}

1. This Selected Issues paper provides further background on analytical work discussed in the Staff Report for the Mexico 2008 Article IV Consultation.

\section{The Significance of U.S. Regional Economic Conditions for Remittances to Mexico.}

Chapter I's statistical analysis shows that workers' remittances to Mexico are indeed sensitive to economic conditions in certain parts of the United States - but not necessarily to the overall U.S. economy's business cycle. Because the majority of persons likely to send remittances to Mexico are geographically concentrated in a small number of the 50 U.S. states, and because business cycles can be quite heterogeneous across those states, it turns out that the overall U.S. business cycle does little to explain fluctuations in remittances to Mexico. However, employment conditions in some parts of the U.S. - including especially California, Texas and other states bordering Mexico-go a long way to explain fluctuations in remittances. The analysis also finds that remittances are particularly sensitive to employment conditions in the U.S. construction sector. The results confirm that remittances are a potential channel of transmission of external shocks from the U.S. to Mexico.

\section{Exchange Rate Exposure of the Mexican Corporate Sector: Progress and Remaining}

Vulnerabilities. Chapter II examines the currency risk exposure of non-financial corporates in Mexico, with reference also to several other countries. Drawing on publicly-available data, the study finds that in general Mexican companies' exposure to peso depreciation has been reduced substantially over the years; if anything, exposure to peso appreciation has grown. A second approach, based on the reactions of stock prices to peso fluctuations, also suggests that exposure to peso depreciation has declined over time. The chapter cautions, however, that publicly available data, and information utilized by stock market participants, may not give a complete picture of corporates' positions, particularly with regard to derivatives. This possibility is highlighted by recent cases in which unusual movements of the peso/dollar exchange rate triggered large losses for a number of firms. The chapter reviews this episode and what has been learned from it, concluding that markets were surprised by these companies' exposures, and suggests some policy lessons.

\section{Examining Macro-financial Linkages in the Mexican Banking Sector Using Estimated}

Credit Risk Indicators. Chapter III studies the condition of the Mexican banking sector, and the macro-financial factors that affect it. The methodology, based on Merton's contingent claims framework, constructs and estimates indicators of bank credit risk, such as the probability that a bank will default on its debt. While the chapter cautions against interpreting the levels of such estimated credit risk indicators literally, it finds that they do move in a sensible way over time. The indicators are also found to be correlated with traditional financial stability indicators such as NPLs, and moreover to be leading indicators of NPLs. This suggests that the new indicators can be a useful addition to the toolkit for analysis of banks' condition and also help understanding the macro-financial factors that affect banks. On the latter, the bank finds linkages to external financial market volatility, domestic interest rates, and economic activity. 


\section{The Significance OF U.S. Regional ECONOMiC Conditions For RemitTances to MEXICO $^{1}$}

1. Are remittances to Mexico sensitive to the U.S. business cycle, so that they represent a channel of transmission of external shocks from the U.S. to Mexico? If so, why have previous studies had difficulty confirming such a linkage? And do remittances respond to economic fluctuations in Mexico, in a manner that represents a buffering mechanism to adverse shocks?

2. This chapter summarizes a recent econometric investigation (Magnusson, 2008) of the cyclical determinants of remittances to Mexico. The key results are:

- The aggregate U.S. business cycle is not necessarily relevant for remittances.

- However, remittances to Mexico do show a significant relationship with employment conditions in certain regions of the U.S. Moreover, employment conditions in the U.S. construction sector seem to be especially important.

- $\quad$ At the same time, some evidence suggests that remittances from the U.S. respond positively to a fall in income back home in Mexico. There are also some signs that remittances are positively affected by a depreciation of the peso.

3. To explain why the aggregate U.S. business cycle does little to explain fluctuations in remittances to Mexico, the study emphasizes two essential facts: (i) the majority of persons likely to send remittances to Mexico are geographically concentrated in a small number of U.S. states, and (ii) business cycle conditions can be quite heterogeneous across states. In particular:

- The location of remitters within the U.S. is not uniform. Although data on the location of persons sending remittances to Mexico is not available, there is good reason to believe these persons to be relatively concentrated in certain U.S. states. The distribution of remitters across the U.S. is likely to resemble the distribution of the U.S. Hispanic population (since Mexicans represent about 2/3 of that group). The geographical pattern of issuance of matricula consular identity cards by Mexican consulates in the U.S. also supports this idea. In both distributions, California and Texas are especially important, and the four U.S-Mexico border states together account for more than 60 percent of the respective totals.

\footnotetext{
${ }^{1}$ Prepared by Kristin Magnusson. This chapter summarizes findings of a paper prepared by Ms. Magnusson while visiting the IMF's Western Hemisphere Department in 2008 ("The Impact of U.S. Regional Business Cycles on Remittances to Latin America", mimeo, IMF/Stockholm School of Economics). More detailed information can be requested at this address: Kristin.Magnusson@hhs.se
} 
- $\quad$ Regional business cycles can vary substantially within the U.S. To highlight this point, the study compares employment conditions in California (which has by far the highest Mexican population density of any U.S. state, in addition to being the most populous state) with the same variable in each of the other U.S. states. As apparent from Figure 1, employment in some states is highly correlated with employment in California. However, California's correlation with aggregate U.S. employment is below +0.5 , and its correlation with many other states is much less, or even negative.

Figure 1. Correlations Between Employment Cycle in California and Other U.S. States

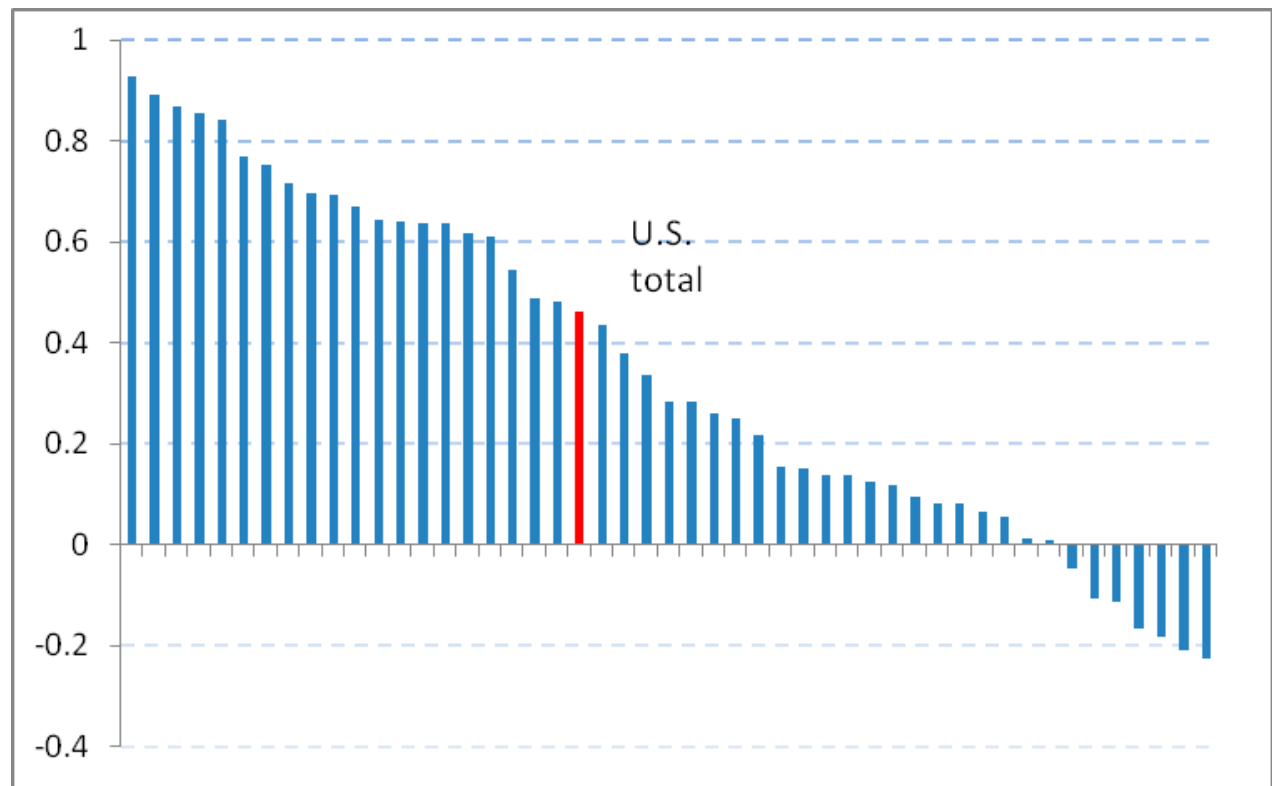

X-axis: Comovement between California, other U.S. states and total U.S. employment, ordered by magnitude. Y-axis: Size of correlation coefficient. Source: U.S. Bureau of Labor Statistics, Current Employment Survey. Note: Correlations are contemporaneous and between cyclical components of HP-filtered and logged data.

\section{Locating the Linkages: Where are the U.S. Determinants of Remittances to Mexico?}

4. Together, the above stylized facts explain why previous econometric studies have not found a systematic link between the U.S. business cycle and remittances to Mexico: the aggregate U.S. business cycle contains a substantial amount of "noise" from states and regions that are of little importance to remitters' income.

5. To address this problem, Magnusson (2008) constructs a "Mexican-weighted" index of U.S. employment conditions. That is, state-level employment data is aggregated after first applying weights for each state's share of the U.S. Hispanic population. Although this index can only be an imperfect proxy for remitters' employment conditions, it turns out to be positively and significantly associated with remittances to Mexico-while total U.S. employment is not. In a second approach, a simple aggregate of employment in the U.S. 
states bordering Mexico also turns out be significantly positively related to remittances, even when controlling for the aggregate U.S. business cycle.

\section{How Strong are the U.S. Linkages to Remittances Received by Mexico?}

6. When the aggregate U.S. economy experiences a downturn, the effect on remittances to Mexico will depend on whether conditions in certain parts of the U.S. are moving in line with the aggregate U.S. economy. Magnusson (2008) also shows that the effect will depend on sectoral performance - especially on whether employment in the construction sector is doing better or worse than overall U.S. employment.

7. The results of this study suggest that a 1 percent decline in "Mexican-weighted" total employment seems to reduce remittances by 2 percent (other variables constant). A 1 percent decline in Mexican-weighted construction sector employment seems to reduce remittances by 11 percent.

\section{What are the Implications for Mexico of a Downturn in Remittances?}

8. Remittances to Mexico are large enough to be of macroeconomic and social significance to the country. Remittances are especially important for certain regions of Mexico with high rates of emigration, and for many low-income households where they may constitute a sizable share of total income. Moreover, because there is likely to be a high propensity to consume out of income from remittances, a decline in such income is likely to have a non-negligible impact on domestic demand and economic activity.

\section{To put this downside risk in perspective, it should be noted that annual} remittances to Mexico — although among the world's highest in dollar terms — are in the neighborhood of $2 \frac{1}{2}$ percent of GDP. The aggregate Mexican economy therefore has much less to lose from a decline in remittances than do some other countries, where remittances can be 20 percent of GDP or more.

10. Moreover, the study finds some evidence—although not as strong —of two potentially mitigating factors. Controlling for the effect of U.S. employment fluctuations, it seems that remittances to Mexico respond positively to deteriorating economic conditions back home in Mexico, providing some buffer to the shock coming from the U.S. Also, there is some sign that remittances respond positively to a depreciation of the peso, and so could help to cushion or mitigate adverse external shocks. 


\section{Exchange Rate Exposure of the Mexican Corporate Sector: Progress AND Remaining VulNerabiLities ${ }^{2}$}

11. The goal of reducing exposure to risk of currency depreciation has received much attention over the last decade. It is well-known that countries such as Mexico have made great progress on this front, most notably on the part of the public sector. Moreover, Mexican banks are subject to close regulations limiting their exposure to currency movements (in both directions). Assessing the currency risk exposure of the nonfinancial private sector, however, tends to be more difficult, as exposures can differ across companies and are not subject to regulatory limits.

\section{A recent IMF study} (Kamil and Sutton, 2008) shows that over the last decade, listed firms in Mexico and Brazil have

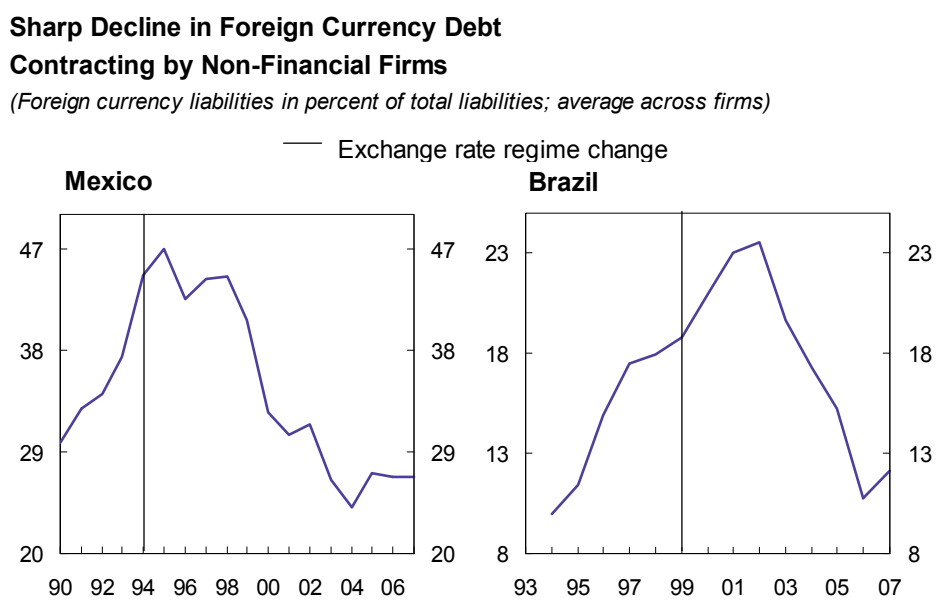

Better Use of Natural Currency Hedging

(Foreign currency liabilities in percent of exports plus foreign currency assets; median across firms)

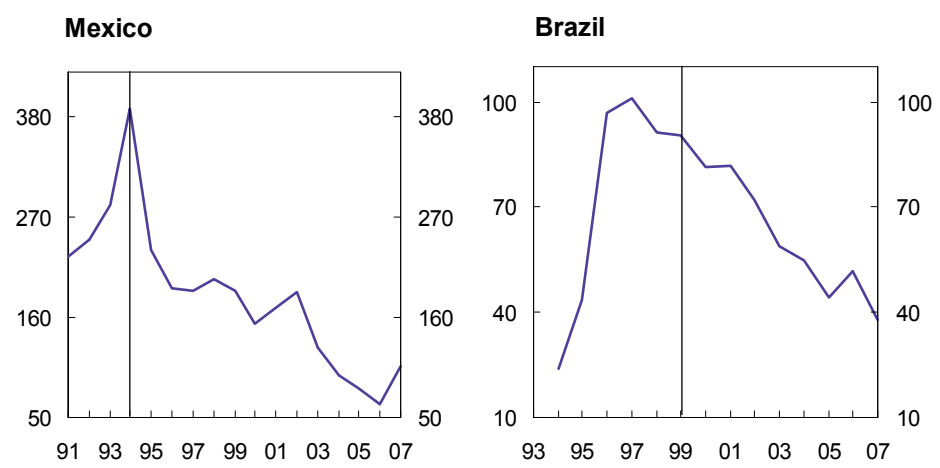
cut their vulnerability to exchange rate risk by reducing currency mismatches in their balance sheets. Firms have relied less on foreign currency financing and those with such financing have been more likely to have natural hedges such as dollar export earnings and dollar assets to offset the currency risk arising from their dollar debts.

\section{In that favorable context, recent losses on currency derivatives held by firms in} Mexico and Brazil have been one of the unwelcome surprises of the global financial crisis. The financial turbulence in October 2008 revealed substantial off-balance-sheet currency exposures associated with "overhedged" or speculative derivative positions in a number of large corporations.

\footnotetext{
${ }^{2}$ Prepared by Herman Kamil and Chris Walker. The discussion here builds on the analysis presented in the IMF's Regional Economic Outlook for the Western Hemisphere (Chapter 5), October 2008, prepared by Herman Kamil and Ben Sutton.
} 


\section{Currency derivative exposures reported by firms in Mexico often involved} currency options, either traded directly by the firm or embedded in a contract, bought from global investment banks and settled in the offshore OTC markets. These positions reportedly were taken with the aim of profiting from local currency appreciation, interest rate differentials, or both. Many of the trades were undertaken during a period of unusually low peso volatility. The low realized volatility of the Mexican peso (MXN) tended to lower expectations for future volatility, and so worked to reduce both implied volatility and the price of option premiums. Given the use of options in the creation of the structured products sold to exporters, many of the resulting positions had nonlinear payoff structures whereby losses accumulated more rapidly after local currencies depreciated past a certain strike price. ${ }^{3}$ When market volatility jumped after the September 2008 Lehman Brothers bankruptcy, many of these positions came to light as the holders scrambled to meet their margin calls.

\section{Implied Volatilities from Currency Options Prices}

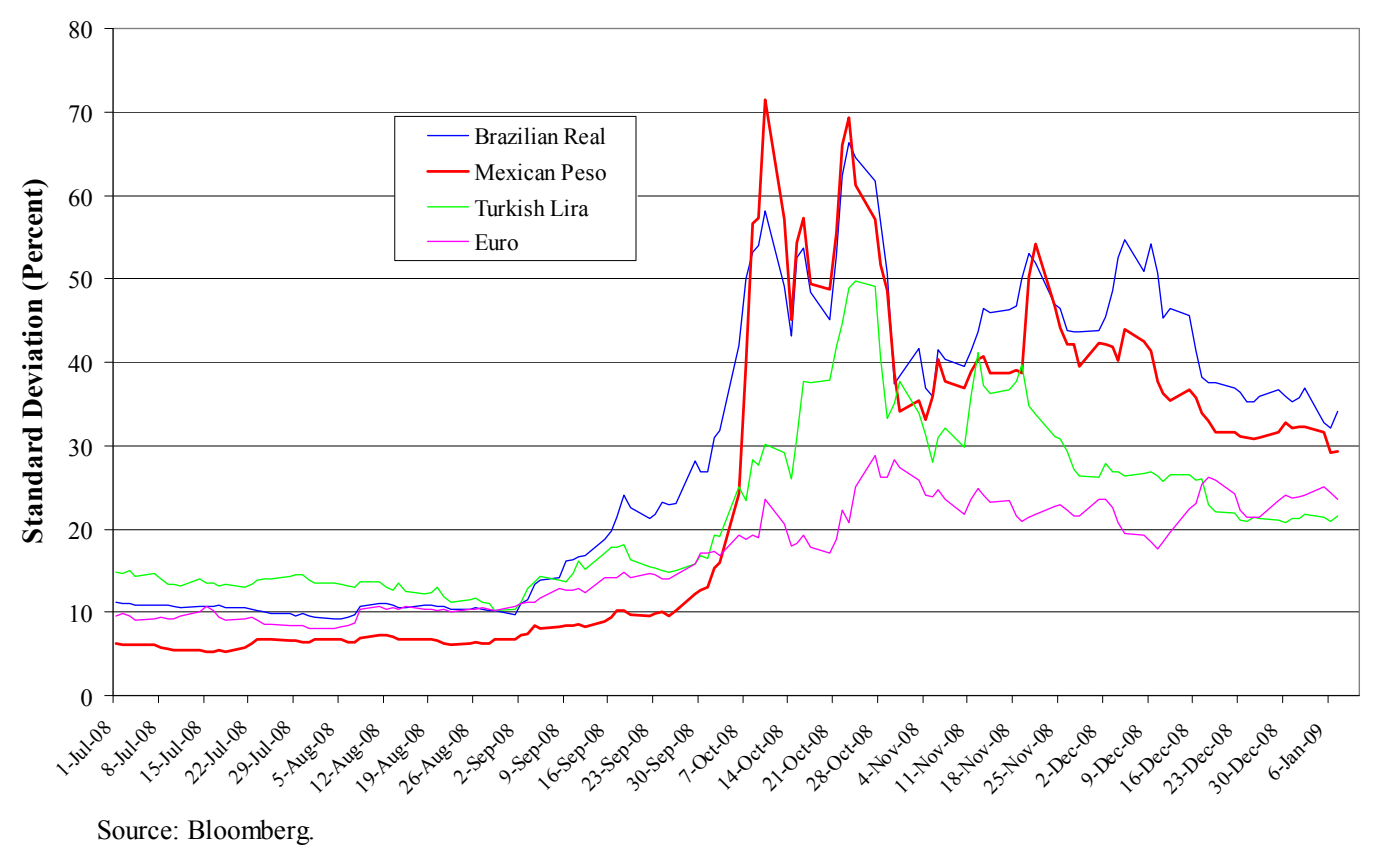

\footnotetext{
${ }^{3}$ While there was a large variety of complex contracts, the common feature among them was that these companies would have the right to sell U.S. dollars (USD) at above-market prices (clients were long USD put options when USD/MXN traded below specified strikes), but the obligation to sell USD at below-market levels precisely when the MXN was trading weak vis-à-vis the USD (i.e., these structures normally specified levels above which clients would become short USD call options). Furthermore, as a means to reduce upfront costs, these structures involved small notional amounts to profit from MXN appreciation moves, but larger notional amounts when MXN depreciated against the USD.
} 


\section{These exposures in Mexico were similar in structure to other types of risky} currency derivative trades identified in Brazil, and also South Korea. In all three countries, some corporates entered into levered option structures, either as an outright bet against depreciation of the domestic currency or as a source of cheaper but riskier funding. While these transactions were profitable when the domestic currency was appreciating, or for as long as exchange rates did not fluctuate too much, losses did mount suddenly when the currencies depreciated sharply in the face of a global risk repricing. ${ }^{4}$

\section{The magnitude of companies' losses on currency positions is difficult to know} precisely, but in countries such as Brazil and Mexico it was large enough to prompt a significant response from the central banks. Exposure to currency risk through derivatives led to financial stresses and threatened to trigger a potential amplification of currency depreciation, as firms increased their demand for dollars when asked by their counterparties for additional collateral to cover their mark-to-market losses. In Mexico, it appears that the biggest losses were by Comercial Mexicana (Comerci), Gruma, Vitro, Cemex and Alfa. There has been one bankruptcy filing (Comerci), and several work-outs are actively in process. The large losses on currency positions, led to an extraordinary demand for dollars. This prompted the Bank of Mexico to intervene in the FX market, for the first time in a decade, to relieve liquidity pressures, selling about 10 percent of its international reserves in a 3-day period. The special intervention measure was designed to meet an exceptional demand for dollars that had resulted from the recent derivatives losses of a number of large companies, rather than at permanently preventing a depreciation of the domestic currency.

\section{Market participants seem to have been caught by surprise by the large open FX} derivative position of some corporates. The stock market reaction after the announcement by some firms of heavy losses on derivative positions suggests that the currency exposure to derivative positions was "news" to the market — at least for many of the firms that suffered significant losses. To gauge a firm's overall foreign currency exposure as priced by the market on the eve of the mid-September 2008 Lehman Brothers bankruptcy, we estimated the contemporaneous impact of exchange rate movements on a firm's stock-market valuation. ${ }^{5}$ Stock prices' reaction to exchange rate changes should, in principle, summarize

\footnotetext{
${ }^{4}$ In Korea, in a common arrangement sometimes described as a "knock-in knock-out" (KIKO) structure, an exporter would receive an at-the-money call option that would pay off when the local currency appreciated. In lieu of paying the premium for this benefit, however, the exporter would write one or more out-of-the-money put options on the currency. While the put options would require the exporter to make payment in the event of a currency depreciation past a certain strike price, at the time that the options were written the currencies in question had all gone through sustained periods of appreciation. As a result, many market participants believed that any bouts of depreciation would be small and temporary, and would not reach the strike (knock-out) prices in the hedging structures.

${ }^{5}$ In estimating the effect of exchange rates on firms' stock prices, controls are introduced to account for other factors that may simultaneously affect the value of the firm, such as world stock market returns and world commodity prices (see Chapter 5 of the IMF's October 2008 Regional Economic Outlook for the Western Hemisphere for more details on the methodology). Note that this estimation assumes a linear relationship
} 
the multiple channels through which exchange rate fluctuations can affect firms' value, including derivatives positions. Our results suggest that only two of the five firms reported to have had significant derivative losses exhibited a negative stock market perception of exchange rate exposure (i.e, nominal share values are adversely affected by a depreciation) in the run-up to the October crisis.

\section{To what extent has the risk associated with these currency-based structures}

diminished? While we cannot answer this question with certainty, currency options prices can provide information about the perceived risk of a sudden unwind. Because a company seeking to limit the damage from a short dollar position could cap its losses by purchasing local currency puts (i.e., dollar calls) the relative price of puts versus calls - known as a "risk reversal" - can provide a gauge of market anxiety. As shown in the chart, this measure reached very high levels for Brazil and Mexico in late October, but rose only negligibly in the case of the euro, and moderately in the case of Turkey, where such currency-based structures were reportedly not as much of an issue. Subsequently, much of this increase was undone in December.

\section{Risk Reversals}

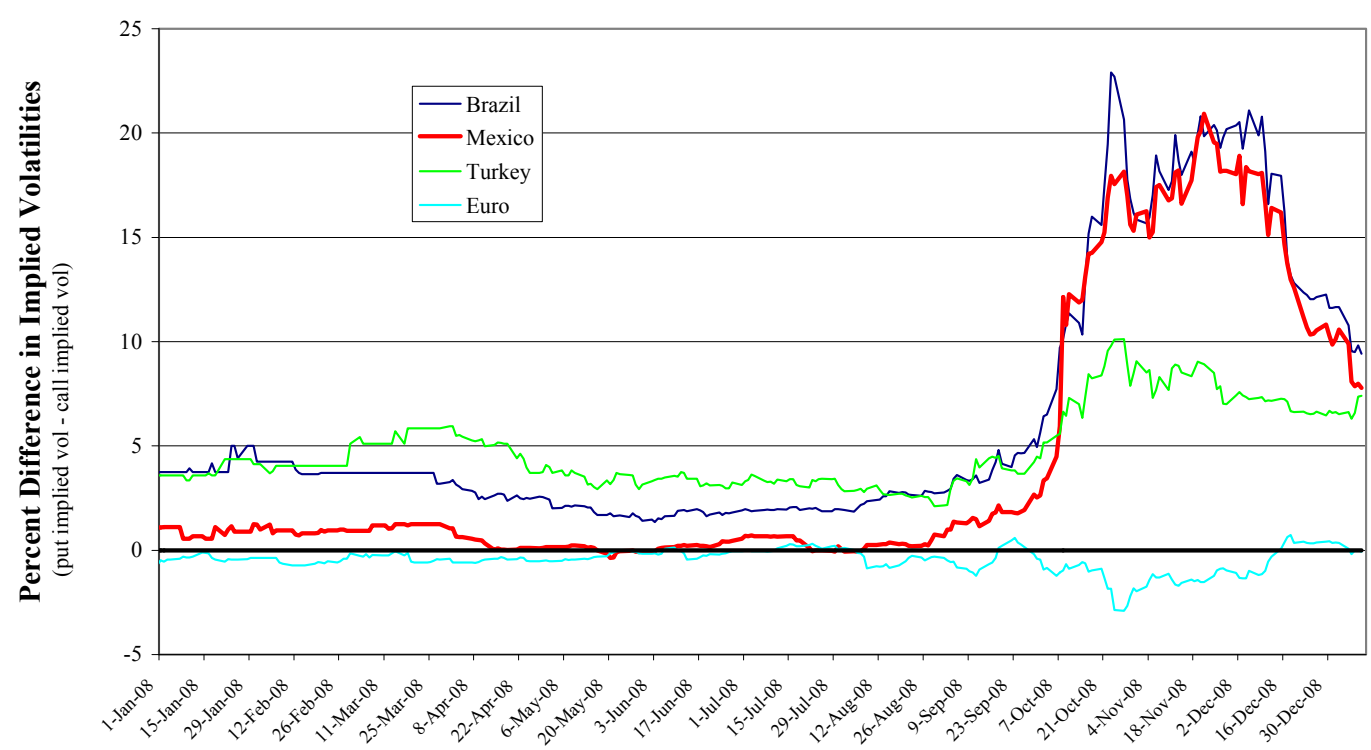

Note: Risk reversals show asymmetry in options prices. The greater the price of local currency puts relative to local currency calls, the higher the risk reversal, and the higher the relative price of insuring against local currency depreciation.

Source: Bloomberg.

between stock returns and exchange rates, whereas some of the FX effects may be non-linear (for example, due to the nature of hedging contracts). 
Adjusted Risk Reversals

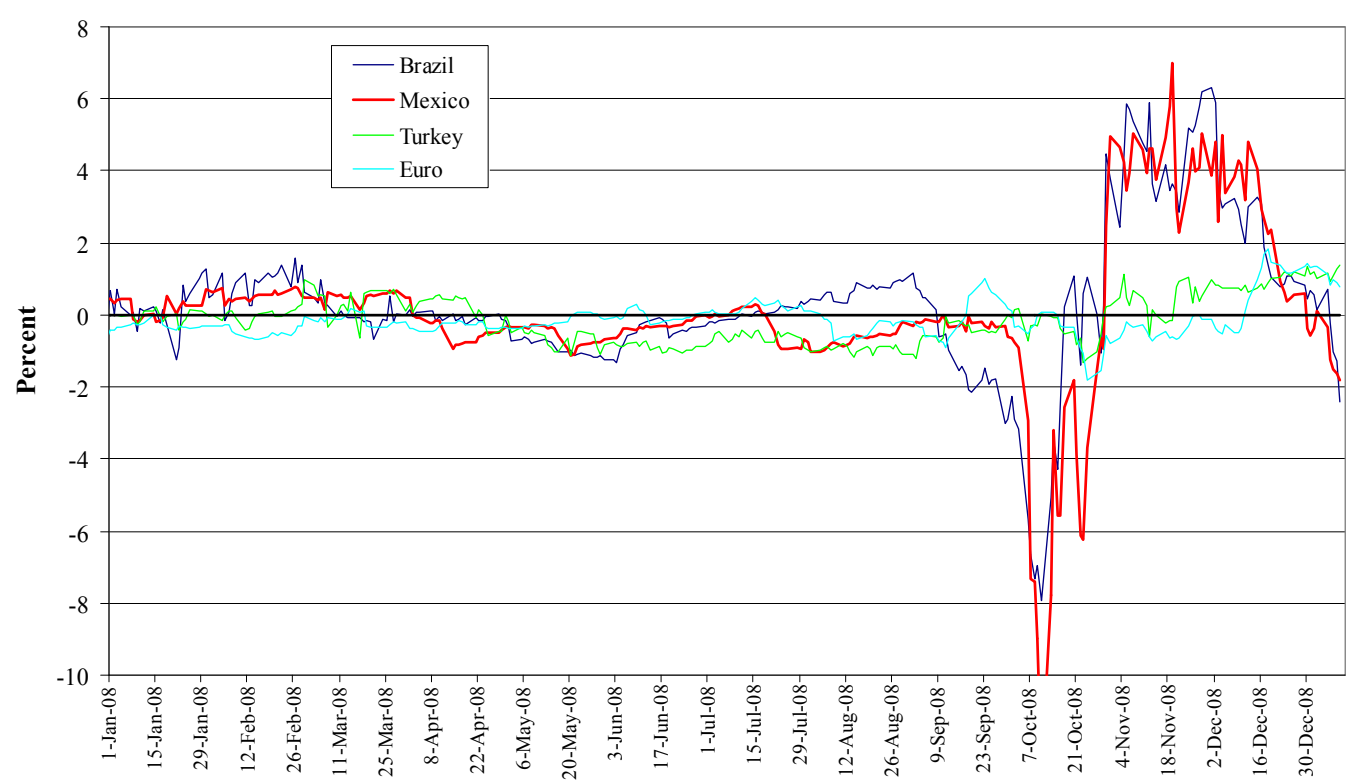

Note: Adjusted risk reversals are obtained by regressing the risk reversal measure on the corresponding average implied volatility. The indicators shown are the residuals from the regressions.

Source: Bloomberg.

19. In the cases of Mexico and Brazil, the degree of market stress signaled by risk reversals recently differed from the stress shown by other indicators of risk appetite. In fact there is some correlation between risk reversals and more general market measures of risk appetite such as currency implied volatilities or the VIX equity market volatility index, so we also consider an "adjusted" risk reversal measure (obtained by regressing the above risk reversal measure on the corresponding implied volatility, and using the resulting unexplained residual as the indicator). The adjusted measures still show a substantial increase in implied demand for a hedge against depreciation, some weeks after the currency mismatches were being reported. While these measures do not themselves necessarily indicate heavy corporate derivatives exposure, they do show an unusually high demandeven taking into account the environment of reduced risk appetite-for a hedge against local currency depreciation. However, by the end of 2008, the adjusted measure has returned to near zero for both Mexico and Brazil, pointing to a drop in the relative demand for hedging depreciation risk.

\section{Policy Implications}

20. Looking across the recent experience of large FX derivatives losses in several emerging market countries, it appears that more and better information will be needed for markets and authorities to better assess in the future any build up of systemic risks associated to derivative trading. This requires reviewing transparency, disclosure and 
reporting rules. Unless accounting standards prevent it, for example, there may often be incentives for companies to engage in "cost-reduction" derivative transactions by hiding the associated risk. Information requirements may also need to better reveal firms' derivative strategies, potential gains and losses under different scenarios, and the kind of collateral being posted. This will be important for the authorities and investors to ascertain how these financial contracts are structured and how well they match the underlying flow of export revenues that they were ostensibly meant to hedge. ${ }^{6}$ Such information is essential for investors to impose market discipline when derivatives strategies create excessive risk. In the case of Mexico, the authorities have indicated that they consider that existing derivatives reporting requirements are broadly adequate but that implementation and enforcement must be improved.

\section{Micro-prudential regulation needs to focus on incentives of all relevant players.}

The recent episodes in Mexico and other countries may reflect varying combinations of failures of governance at the firm level (poor risk management), failures of transparency and disclosure from suppliers of instruments (banks that failed to remind options buyers of the embedded risk), and lack of information provided to regulators and markets on the extent of currency exposure associated with derivative positions. ${ }^{7}$

\section{Going forward, a combination of careful monitoring of over-the-counter} transactions, and migration of some transactions into regulated exchanges, could work to reduce systemic risk. There seems to be a good case for tighter oversight and registration of the positions - many of which were over-the-counter - that led to the recent problems. While the Mexican authorities do have mechanisms in place to gather data on onshore transactions (through banks operating domestically), some of the problem relates to offshore transactions, which are generally more difficult to regulate and monitor. In principle, greater international cooperation among regulatory authorities could play an important role in addressing this problem.

\footnotetext{
${ }^{6}$ It is important to note that some of these option structures are very hard to value, which adds a dimension of complexity well beyond simple disclosure. In the Mexican case, many structures were selling protection against volatility and the domestic currency past the strike price of 13 pesos to the dollar, and apparently few believed at the time that this "tail event" was plausible. Reportedly, the perception among local corporations was that "excessively high" levels (vis-à-vis history) of MXN/USD were unlikely, given Mexico's economic fundamental outlook or recent trading ranges. Indeed, history suggested that a scenario in which MXN/USD rose "too much" (e.g., 25 percent or more in a single month) had less than 3 percent probability; on that basis, standard value-at-risk calculations would miss the size of the eventual losses.

${ }^{7}$ In some cases, activities that began as responsible hedging, e.g., appropriate to exporters' needs, over time expanded into aggressive speculation, as strong positive returns pulled in more market players and induced bankers to design new investment products to appeal to the new clientele.
} 


\section{ESTimating Default FreQuenCES AND MACROFINANCIAL LinKageS IN THE MEXICAN BANKING SYSTEM ${ }^{8}$}

\section{This paper uses credit risk indicators estimated using balance sheet data to} assess vulnerabilities of the Mexican banking sector-and potential asymmetric effects of large movements in a shock variable. Our set of estimated credit risk indicators are shown to be leading indicators of traditional financial sector indicators (FSIs), in particular of non-performing loans (NPLs), thereby potentially providing useful early warning signals. External and domestic financial variables, and activity indicators, are found to be significant determinants of financial sector soundness. Individual banks show heterogeneity in their sensitivities to macro-financial variables, possibly reflecting their different business models.

\section{A. Background: A Few Stylized Facts About the Mexican Banking System}

24. A few characteristics of the Mexican banking sector are important background:

- $\quad$ The banking sector has grown at a fast rate in recent years. This growth was notably driven by consumer and mortgage lending, which both showed high percentage growth rates over the last five years. More recently, consumer lending has slowed, while credit to firms picked up in the last two years.

- Levels of financial intermediation — although increasing — are still low, with bank credit to the private sector substantially lower than in comparator countries. Banking assets are relatively small, with an important share invested in public debt.

- $\quad$ Traditional FSIs reflect the strength of Mexican banks. NPLs are at low levels, around 3 percent overall, although in some categories they have increased sharply recently. Banks are well capitalized — significantly above regulatory requirementsand have been highly profitable. Credit expansion has been funded mostly through an expansion of the deposit base, and reliance on external financing is limited.

- The banking sector is highly concentrated and dominated by foreign-owned banks. The six largest banks account for more than 80 percent of banking sector assets - of these banks, five are foreign-owned.

- $\quad$ As suggested by the Bank of Mexico's Report on the Financial System, banks may be classified into four main types, with different business models-large banks (6) with a diversified credit portfolio; small and medium-sized banks (17), lending mostly to SMEs; small subsidiaries of foreign banks (14), mostly operating as investment boutiques; and banks associated with commercial and retail groups (BACCs), which focus on consumer lending. The panorama has evolved in recent years, with new

\footnotetext{
${ }^{8}$ Prepared by Rodolphe Blavy and Marcos Souto.
} 
entrants and greater competition, focused especially on previously under-banked segments of the population.

\section{These stylized facts help guide our investigation of banks' condition, in} particular: what do credit risk indicators suggest, in light of the recent apparent deterioration in credit quality? In the current context of heightened volatility and global financial turmoil, what is the expected sensitivity of banks to potential shocks, and which types of banks may be more affected by such shocks?

\section{B. Application of the Merton Framework to Mexican Banks}

\section{The Merton contingent claims framework ${ }^{9}(1973,1974)$ offers important} advantages over traditional balance sheet vulnerability analyses, including by incorporating the role of volatility explicitly. Changes in risk are especially important in times of stress when small shocks can trigger systemic repercussions. In this framework, a set of credit risk indicators can be estimated, including the expected default frequency (EDF) and the distance-to-distress, i.e., a measure of how far a firm or bank is from defaulting (for technical details, see Gapen et al., 2004, 2005).

\section{In the case of Mexico, we must use book value data, rather than market} valuations ${ }^{10}$, to estimate credit risk indicators, because most large banks are not listed in the Mexican equity market. This approach has important limitations, including missing the forward-looking nature of market-based information. Acknowledging these, we investigate whether our indicators providing additional information on banking soundness, notably by capturing asset volatility. We use quarterly bank balance sheet data from the CNBV, Mexico's banking supervisory agency, for the December 1997-June 2008 period, for 48 banks.

\section{The credit risk indicators presented here can be considered as a complement to} other measures of financial soundness, with some limitations. We interpret them as indicators rather than as direct estimates of default probabilities. Data limitations (lack of equity market data and high frequency data) restrict the amount of volatility that is captured by the estimated indicators. Further, the 1998-2008 period is characterized by a strong trend component and historically low volatility, possibly imparting a downward bias to the estimated risks.

\footnotetext{
${ }^{9}$ Merton models the equity of a firm as a claim on the contingent value of total assets. That is, in the event of a firm's default, equity holders are junior claimants and will receive either nothing or the difference between total assets and total debt. This payoff structure is similar to that of a call option. So, with market-based information on equity and equity volatility, one can estimate the implied value for assets and assets volatility, using the Black and Scholes option formula. Once assets' value and volatility have been determined, it is then possible to estimate a set of credit risk indicators, including expected default frequency (EDF).

${ }^{10}$ As reported in the working paper version of this study, market data is available for a few banks and for those we estimate market-based risk indicators as well. It turns out that market and book value indicators show similar dynamics.
} 


\section{Main Results}

29. The estimated credit risk indicators seem to capture key developments in the banking sector (Figure 1). A trend decline in the riskiness of Mexican banks is observed. The risk measures capture the economic recession of 2001-02 and the uncertainty preceding the 2006 presidential election, and also have risen slightly in recent quarters, a time when traditional indicators have been suggesting some deterioration in credit quality. Overall, the EDF numbers are quite low, although again we caution against interpreting them literally.

30. We find that the EDF is a leading indicator of some traditional FSIs. The two variables are closely associated in regression analysis, and moreover the EDF is shown to Granger cause NPLs.

31. We also find that domestic and external macro-financial variables are closely associated with our indicators of banking soundness, with some heterogeneity across banks. Global volatility - as captured by the VIX index — and domestic interest rates are significant determinants of the average expected default probability. When looking at individual banks, results vary substantially but domestic activity and U.S. growth are generally associated with lower credit risks, while increased volatility worsens credit risks (Table 1).

32. Our findings are comparable with similar studies of banks in other emerging markets in Latin America. Using market data, Dale and Walsh (2008, on Chile), Souto, Tabak, and Vazquez (2008, on Brazil) and Abrego and Souto (2008, on Colombia) find that bank soundness is significantly related to macro-financial variables, while also finding evidence of heterogeneity between banks. Using book-value data, Souto (2008) finds that CCA indicators capture well the episodes of bank stress in Uruguay. 


\section{References}

Abrego, L. and M. R. Souto, 2008, “The Colombian Banking Sector - A Contingent Claims Analysis," Selected Issues Paper, IMF 2008 Article IV Consultation, forthcoming.

Blavy, R., and M. R. Souto, 2009, "Estimating Default Frequencies and Macrofinancial Linkages in the Mexican Banking Sector," IMF Working Paper, forthcoming.

Gapen, Michael T., Dale F. Gray, Cheng Hoon Lim, and Yingbin Xiao, 2005, "Measuring and Analyzing Sovereign Risk with Contingent Claims," IMF Working Paper 05/155, (Washington: International Monetary Fund), available on the web at: http://www.imf.org/external/pubs/ft/wp/2005/wp05155.pdf

-, Michael T., Dale F. Gray, Yingbin Xiao, and Cheng Hoon Lim, 2004, "The Contingent Claims Approach to Corporate Vulnerability Analysis: Estimating Default Risk and Economy-wide Risk Transfer," IMF Working Paper 04/121 (Washington: International Monetary Fund), available on the web at: http://www.imf.org/external/pubs/ft/wp/2004/wp04121.pdf

Gray, Dale F. and J. Walsh, 2008, "Factor Model for Stress-testing with a Contingent Claims Model of the Chilean Banking System," IMF Working Paper 08/89 (Washington: International Monetary Fund), available on the web at: http://www.imf.org/external/pubs/ft/wp/2008/wp0889.pdf

Merton, Robert C., 1973, "Theory of Rational Option Pricing," Bell Journal of Economics and Management Science, Vol. 4, pp. 141-83.

, 1974, “On the Pricing of Corporate Debt: The Risk Structure of Interest Rates," Journal of Finance, Vol. 29 (May), pp. 449-70.

Souto, M. R., 2008, "Has the Uruguayan Financial System Become More Resilient to Shocks? An Analysis Adapting the Merton Framework to a Country Without Equity Market Data," IMF Occasional Paper No. 263.

, B. M. Tabak, and F. Vazquez, 2008, "Linking Financial and Macroeconomic Factors to Credit Risk Indicators of Brazilian Banks" Central Bank of Brazil Working Paper, forthcoming. 
Figure 1. Mexican Banking Sector-Estimated Risk Indicators, December 1998 - June 2008 1/
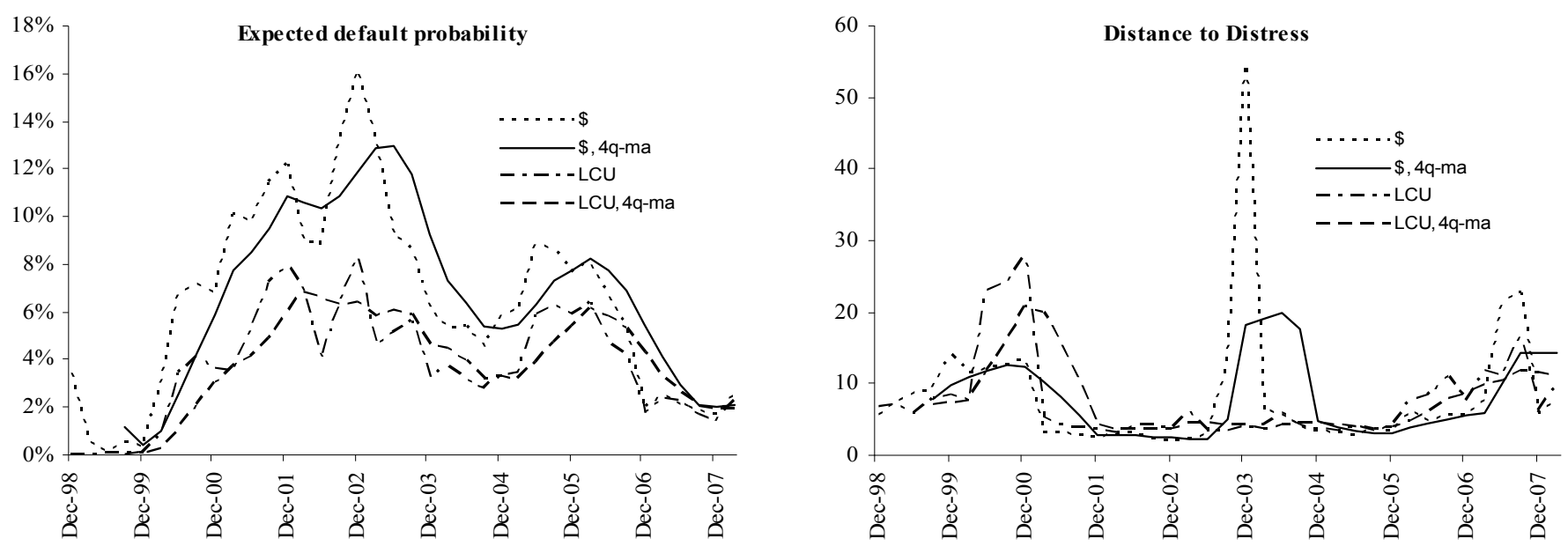

1/ Indicators shown are asset-weighted averages for local currency ("LCU”) and U.S. dollar ("\$”) credit risk indicators (4-quarter moving averages are also presented). The sample comprises 26 banks for which data are available across the 1998-2008 period.

Table 1. Determinants of Individual Banks' EDFs: Results of Stepwise Regressions ${ }^{1 / 2 / 31}$

\begin{tabular}{|c|c|c|c|c|c|c|c|c|c|}
\hline Bank & $\begin{array}{r}\text { Domestic } \\
\text { Industrial } \\
\text { Production } \\
\end{array}$ & $\begin{array}{r}\text { Domestic } \\
\text { Consumer } \\
\text { Prices } \\
\end{array}$ & $\begin{array}{r}\text { Domestic } \\
\text { Nominal } \\
\text { Interest Rate } \\
\end{array}$ & $\begin{array}{r}\text { Economic } \\
\text { Activity }\end{array}$ & $\begin{array}{r}\text { Forward } \\
\text { Exch. Rate } \\
\text { (Peso/Dollar) } \\
\end{array}$ & VIX & $\begin{array}{l}\text { US Nominal } \\
\text { Interest Rate }\end{array}$ & $\begin{array}{l}\text { US Industrial } \\
\text { Production }\end{array}$ & R-Square \\
\hline 1 & -1.00 & $\ldots$ & -0.68 & $\ldots$ & -0.24 & $\ldots$ & 0.00 & $\ldots$ & 0.40 \\
\hline 2 & 10.61 & 0.04 & $\ldots$ & $\ldots$ & 0.15 & $\ldots$ & 0.00 & $\ldots$ & 0.49 \\
\hline 3 & $\ldots$ & $\ldots$ & $\ldots$ & $\ldots$ & $\ldots$ & $\ldots$ & 0.01 & $\ldots$ & 0.19 \\
\hline 4 & $\ldots$ & $\ldots$ & $\ldots$ & $\ldots$ & $\ldots$ & $\ldots$ & -0.01 & $\ldots$ & 0.23 \\
\hline 5 & $\ldots$ & -0.43 & 2.14 & $\ldots$ & $\ldots$ & $\ldots$ & $\ldots$ & -0.01 & 0.46 \\
\hline 6 & $\ldots$ & -0.47 & $\ldots$ & $\ldots$ & $\ldots$ & $\ldots$ & 0.03 & -0.02 & 0.66 \\
\hline 7 & $\ldots$ & $\ldots$ & $\ldots$ & $\ldots$ & $\ldots$ & $\ldots$ & 0.00 & $\ldots$ & 0.22 \\
\hline 8 & $\ldots$ & $\ldots$ & $\ldots$ & $\ldots$ & $\ldots$ & $\ldots$ & -0.06 & $\ldots$ & 0.53 \\
\hline 9 & $\ldots$ & -1.46 & $\ldots$ & -1.94 & $\ldots$ & -0.67 & $\ldots$ & $\ldots$ & 0.43 \\
\hline 10 & 6.99 & $\ldots$ & $\ldots$ & $\ldots$ & $\ldots$ & $\ldots$ & -0.12 & 0.04 & 0.52 \\
\hline 11 & $\ldots$ & $\ldots$ & $\ldots$ & $\ldots$ & $\ldots$ & $\ldots$ & -0.03 & 0.01 & 0.43 \\
\hline 12 & $\ldots$ & $\ldots$ & $\ldots$ & $\ldots$ & $\ldots$ & $\ldots$ & -0.06 & $\ldots$ & 0.73 \\
\hline 13 & $\ldots$ & $\ldots$ & -2.95 & $\ldots$ & $\ldots$ & $\ldots$ & 0.02 & -0.01 & 0.63 \\
\hline 14 & $\ldots$ & 0.51 & $\ldots$ & $\ldots$ & $\ldots$ & $\ldots$ & -0.06 & 0.01 & 0.79 \\
\hline 15 & -1.27 & $\ldots$ & $\ldots$ & $\ldots$ & & $\ldots$ & $\ldots$ & 0.00 & 0.32 \\
\hline 16 & -3.69 & $\ldots$ & $\ldots$ & $\ldots$ & 0.81 & $\ldots$ & $\ldots$ & 0.02 & 0.79 \\
\hline 17 & 0.38 & $\ldots$ & $\ldots$ & $\ldots$ & $\ldots$ & $\ldots$ & $\ldots$ & $\ldots$ & 0.42 \\
\hline 18 & $\ldots$ & $\ldots$ & -7.30 & $\ldots$ & $\ldots$ & $\ldots$ & $\ldots$ & $\ldots$ & 0.17 \\
\hline 19 & -4.15 & $\ldots$ & $\ldots$ & $\ldots$ & $\ldots$ & $\ldots$ & $\ldots$ & $\ldots$ & 0.38 \\
\hline 20 & $\ldots$ & $\ldots$ & $\ldots$ & $\ldots$ & -1.58 & $\ldots$ & $\ldots$ & $\ldots$ & 0.13 \\
\hline 21 & $\ldots$ & $\ldots$ & -6.32 & $\ldots$ & & $\ldots$ & -0.03 & $\ldots$ & 0.58 \\
\hline 22 & $\ldots$ & $\ldots$ & -4.25 & $\ldots$ & -0.73 & $\ldots$ & $\ldots$ & -0.01 & 0.64 \\
\hline 23 & $\ldots$ & $\ldots$ & -0.09 & $\ldots$ & $\ldots$ & $\ldots$ & 0.00 & $\ldots$ & 0.62 \\
\hline 24 & 10.61 & $\ldots$ & $\ldots$ & $\ldots$ & $\ldots$ & $\ldots$ & $\ldots$ & $\ldots$ & 0.21 \\
\hline 25 & $\ldots$ & $\ldots$ & $\ldots$ & $\ldots$ & 4.57 & $\ldots$ & $\ldots$ & $\ldots$ & 0.25 \\
\hline 26 & $\ldots$ & $\ldots$ & $\ldots$ & $\ldots$ & & $\ldots$ & $\ldots$ & -0.02 & 0.67 \\
\hline
\end{tabular}

Source: Staff Estimates.

1/ The stepwise regression uses backward elimination. It starts with all explanatory variables and keep eliminating the ones, one-by-one, that are least significant, until ending with a set of factors that are all significant at least at the 10 percent level.

2/ We report results using EDFs computed using local currency balance sheet data. Results using dollar-measured EDFs, and using both measures for distance-to-distress are comparable.

3/ Table is presenting the coefficient results for the last stepwise regression for each bank. Last colimn presents the R-Square for each regression. 